\title{
My Last Bookshelf
}

MAUREEN COBB MABBOTT

As I prepare to move from a large Manhattan apartment to a small room in a retirement home, I find that the thought of this transfer is exhilarating. When, if not now, will I ever indulge my secret passion for traveling light? I shall simply take my comfortable bed, a favorite chair for myself and one for a guest, a chest for storage, some accessories-and books. What books? This question, I confess, puts anguish into my dream of traveling light, may even put some danger into it. It has been observed that book collectors, having disposed of their books, may lose their desire for life.

Except for a ten-year period, my occupation slot on our family income tax form said "housewife" in its space. But I have been a bookish housewife, one who has lifted her spirits not by purchasing a new hat or a pair of earrings but another book, new or old. Married to a scholar, I had a sympathetic partner-and competition for shelf space.

As an enthusiastic amateur, I have followed diverse interests and, in addition to great isolated works, have often read in and around Leonardo da Vinci, D. H. Lawrence, Rainer Maria Rilke. An Oriental period, centered on A Dream of the Red Chamber, The Tale of Genjii, and The Pillow Book, with close attention to the arts, especially of Japan, did much to break down my European provincialism. Then there were the novels. At one period, when good secondhand books were cheap, I collected a 300 -volume library of novels, cataloged, and read most of them.

With a fellow nonscientist I formed a "little library of science." This was made up of Whitehead's Science and the Modern World, Shapley's Of Stars and Men, Julian Huxley's Religion without Revelation, Barnett's The Universe and Dr. Einstein, Bronowski's The Common Sense of Science, and Eiseley's The Immense Journey. To the outer eve six ragged paperbacks, in actuality these were a clus- 
ter of light, a sacred sheaf. There were also the later additions of Charles A. Whitney's story of The Discovery of Our Galaxy (1971) and Fritjof Capra's The Tao of Physics, An Exploration of the Parallels between Modern Physics and Eastern Mysticism (1976). Altogether these science books provide the amateur with a kind of observation platform for the science news that is crowding in on all sides. I leave the books behind but, standing on the platform, I shall be eagerly watching for the news. A current item has me in thrall.

The new insights coming out of particle physics tend to disprove the myth that the cosmos is an inexorable machine. To see the universe evolving like life, like thought, as subject to chance just as our lives are subject to chance, is to deepen our sense that we have a rightful place in nature.-Timothy Ferris, "Beyond Einstein and Newton-on the Frontier of Physics," New York Times Magazine, 9/26/82

"A rightful place in nature"-to deepen my sense of that, as well as to please my aesthetic sense, seems to have been my unconscious desire as I have followed my most absorbing interest of all, poetry past and present. We are always being told that poetry and physics grow closer together. Perhaps they do. Both certainly make the same kind of demands upon what Lewis Thomas calls our peculiarly human birthright, a tolerance for ambiguity. Both help us slip behind the strong defenses the rationalistic mind sets up against bringing to consciousness our deepest intuitions.

Poetry will be better represented on the shelf than any other interest, not only because of my love for it, but also because of the nature of the product. Auden once told us that communication is a ladder. In much of prose, when contact has been made, we kick away the ladder. In poetry, which is a process, we cherish the ladder itself. So much for the formation of my collection. Now for the sad part, its breakup.

Already the limits of space have dictated that all but a small nucleus of the novel library and most of the modern poetry books (after being searched for a personal anthology) be donated to public institutions. The rather costly Leonardo collection, used as a resource for research and travel, has been sold.

What mistakes I shall make I can imagine, but now I am choosing my old-age library, a small shelf for my small room. I am not going to a desert island where no books are. Books will be available, but for this last bookshelf I want to choose from my familiars-books whose rich rewards, so known to me, promise others not yet known.

When I was young, Epictetus and Marcus Aurelius were my men- 
tors. Stoicism seemed a fine control for the exigencies of a world recovering from World War I, and nothing of more point for human endeavor than the statement: "For these too are triflers who have wearied themselves in life by their activity and yet have no object to direct every movement and in a word all their thoughts." Now that I am old, as long as I am strong enough to accept the consolations of philosophy, I shall cherish the Encheiridion and the Meditations; however, I mean to place on the shelf, beside the Greek slave and the Roman emperor, the more worldly Balthasar Gracian. With his Arts of Worldly Wisdom, I shall temper the Stoic "Accept with all your soul everything that happens" with a little forwardlooking self-interest, as for instance: "It is not enough for a careful man not to interfere with others, he must see that they do not interfere with him."

Before I place the next book on the shelf I want to say why, with the exception of Epictetus and Aurelius, the classics are scanted here. I married a man so hooked into the currents of the classical age that my perception of the ancients came to me from him, from the Greek and Roman coins he collected and from our visits to the Metropolitan and British museums, and not from books. I did, however, read the Greek plays in various translations, and I rescue for my shelf one remarkable volume, Edith Hamilton's translation of Three Greek Plays, The Trojan Women, Prometheus Bound and Agamemnon so that I can turn to the Greeks in their own words as far as another language can.

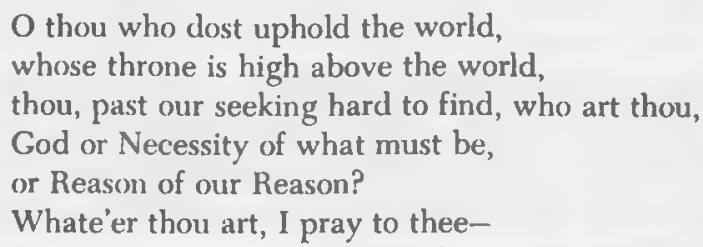

Hecuba's Prayer, The Trojan Women

After my first word-for-word reading of the Holy Bible when I was 12 years old (being driven to this course by the scarcity of books in my father's house), I learned to skip, to find my own on the printed page. This agile exercise never profited me more than when I discovered the Essays of Montaigne. Both these bibles, the holy and the secular (as John Cowper Powys has called the Essays) belong on my last bookshelf. I can find my way among the genealogies and the anecdotes to the passages that speak directly to me. Who more directly? 
We have lived long enough for others: let us live for ourselves, at least this remaining bit of life. Let us bring back our thoughts and intentions to ourselves and our comfort. It is no small business to prepare securely one's retirement: it gives us enough to do without the intrusion of any other concerns. Since God gives us permission to arrange for it, let us pack up our belongings, take leave betimes of the company, and shake off those holdfasts that engage us elsewhere and estrange us from ourselves.-Montaigne, "On Solitude"

A reader, by long-continued reading, finally takes on some of the attributes of the critic and interprets what he reads by what he has read. Montaigne's words shine brighter and carry less of a selfish aura because I remember Epictetus: "If God had committed some orphan to your charge would you have been less careless of him? He has delivered yourself to your care and says, I had no one better to be trusted than you; preserve this person for me, such as he is by nature-modest, faithful, noble, unterrified, dispassionate, tranquil. And will you not preserve him?"

It is this kind of reverberation that makes rereading such a pleasure. I am reminded of Dostoyevsky: "Perhaps it will interest you to know what I do when I am not writing-well, I read. I read a great deal. And it has a curious effect on me. When I reread anything that I knew years ago, I feel fresh powers in myself." One does feel fresh powers in oneself-they are engendered by the books read in the interim.

The Holy Bible, of course, reverberates in and enriches all literature. I am glad, though, that Emily Dickinson hoisted a little flag of affectionate impudence to confound the literal minded:

The Bible is an antique Volume-

Written by faded Men

At the suggestion of Holy Spectres-

Subjects-Bethlehem-

Eden-the ancient Homestead-

Satan-the Brigadier-

Judas-the Great Defaulter-

David-the Troubadour-

Sin-a distinguished Precipice

Others must resist-

Boys that "believe" are very lonesome-

Other Boys are "lost"-

Had but the Tale a warbling Teller-

All the Boys would come-

Orpheus' Sermon captivated-

It did not condemn- 
Shakespeare makes a pointed conclusion about the climate of extremism the Bible sometimes finds itself in.

How sour sweet music is

When time is broke, and no proportion kept!

Richard $1 I, \mathrm{~V}, \mathrm{v}, 42$

And, indeed, the next place on the shelf is for Shakespeare, around whose name there is universal appreciation. On May 10, 1817, Keats wrote to Benjamin Haydon: "I never quite despair and I read Shakespeare-indeed I shall I think never read any other book much ... I am very near agreeing with Hazlitt that Shakespeare is enough for us."

And so am I. The only thing that makes me hesitate is indecisiveness about what edition I want to place on my last bookshelf. It is not the time or place for the variorum or even for the Riverside edition (1974) with its many illustrations, introductions and all the hard words explicated. Some years ago I discovered the Nonesuch edition. This is the one, I think, for poetry and pleasure. Except for a few marginal clarifications, it reproduces the text of the first folio of 1623. No modernizations have been permitted to slur "the authentic accent of the original." I agree with Herbert Farjeon that, when one's eyes and ears have been opened by the old text, the modern has something of the flatness of soda water after champagne. One can see how readable the first folio text is by looking at its version of what Edith Sitwell has said is "in all probability the greatest sonnet in the English language":

Devouring time blunt thou the Lyons pawes, And make the earth devoure her owne sweet brood, Plucke the keene teeth from the fierce Tygers yawes, And burne the long liv'd Phaenix in her blood, Make glad and sorry seasons as thou fleet'st, And do what ere thou wilt swift-footed time

To the wide world and all her fading sweets:

But I forbid thee one most hainous crime, O carve not with thy howers my loves faire brow, Nor draw noe lines there with thine antique pen, Him in thy course untainted doe allow,

For beauties patterne to succeeding men.

Yet doe thy worst ould Time dispight thy wrong, My love shall in my verse ever live young.

D. H. Lawrence, whose perceptions and vitality I early came to rely on, may have inspired the forming of my collection of novels when he said, "The novel can help us to live as nothing else can." 
And, I am sure, a statement I read by Mark Schorer pushed me further into action: "Learning to read novels we slowly learn to read ourselves." Who does not wish to read oneself? I endeavored to collect the best and was experienced enough by now to seek guidance in my choices. However, masterpieces are not the sole sources of knowledge. Wisdom and insight have peered at me from the pages of many a trashy piece of fiction I have read, but if, as Auden said, masterpieces are for holy days, I for one wish to celebrate them.

As I look at my card catalog of the 300 novels, I remember and regret. To some extent in their pages I did learn to read myself. The regret is over leaving this varied company. My short excerpts from 20 of these novels are like lingering handclasps before farewell. I doubt if their names reveal anything, but the excerpts touch chords in my memory and play the themes back to me: Moby-Dick, Scarlet Letter, The Sound and the Fury, Huckleberry Finn, Middlemarch, Portrait of a Lady, Return of the Native, Martin Chuzzlewit, Nostromo, Wuthering Heights, Emma, Women in Love, War and Peace, The Brothers Karamazov, Dead Souls, Dream of the Red Chamber, The Tale of Genjii, Don Quixote, Madame Bovary, and Remembrance of Things Past. The excerpts from some of these books are greater than their sources-I think of "Jonas Chuzzlewit Sets Forth to Murder" from Martin Chuzzlewit. But which novels are for the bookshelf?

By following a spirit trail-a trail that began in my country childhood-I have found the theme that means most to me. It is a sense of "some living connection with the cosmos," as expressed in one of Lawrence's poems. I feel a sense of this connection in the classics, in the Holy Bible, and in Shakespeare. Among other great themes I find it in the novels I have chosen for my bookshelf: Wuthering Heights, Moby-Dick, Remembrance of Things Past, The Sound and the Fury, and The House of Breath. The last is the slightest but William Coyen's novel is haunting, modern, and unequivocal in its theme: "Something in the world links faces and leaves and rivers and woods and wind together and makes of them a string of medallions with all our faces on them, worn forever round our necks, kin.

The novels were chosen because they offer fields for future exploration, though, of course they all do that-War and Peace after four readings! They fit exactly my criterion for the shelf: "books that offer rich rewards, so known to me, promise others not yet known." Moby-Dick is a special case. Since I have worn out and lovingly cremated my 60 -year-old Modern Library edition, a reward 
of retiring at this time is that I can take with me one of the glories of modern bookmaking. This is the Arion Press edition published by the University of California Press, 1981. Moby-Dick is a desert island book for me. I often read passages, any passage, at odd moments and, although I have never done so, some day I may use it for advice or prophecy as some have used the Bible, as Gabriel Betteredge used Robinson Crusoe in The Moonstone.

There is no Lawrence novel on the shelf. I content myself with a small personal anthology of some of the miraculous insights I find in his prose and in placing among my books the "quick" of his uneven genius, his Complete Poems and the volumes of the new Complete Letters as they come from the Cambridge Press. This author as no other has accompanied my life with all the inspiration and aggravation of a difficult elder brother. I do not agree with Aldous Huxley that his philosophy with its insistence on intuition over abstract reasoning is not a good one for old age and failing powers. I find no abstract reasoning, nothing as consoling as Lawrence's intuition.

Birkin looked at the land, at the evening, and was thinking: Well, if mankind is destroyed like Sodom, and there is this beautiful evening with its luminous land and trees, I am satisfied. That which informs it is all there, and can never be lost. After all what is mankind but just one expression of the incomprehensible.

from Women in Love

In the poetry segment of the shelf beside Lawrence I shall place the great white father, Whitman, but not all of his poetry. In addition to some isolated lyrics, what I treasure is the reproduction of the first edition of Leaves of Grass-1855 with Malcolm Cowley's introduction, brought out as a Compass paperback in 1959. Then comes Stephen Mitchell's new translation of the Selected Poetry of Rilke. For 40 years Rilke's poems have been my close companions, and reading this new edition will be like seeing an old friend in a new light. In these volumes my spirit trail has reached a living resource. In the poems of Whitman, Lawrence, and Rilke I feel most deeply a continual awareness of, and a respect, for the integrity of the natural world, and a perception of man's "rightful place" in it.

The bulk of our great lyric inheritance is well served (for this time and place) by four anthologies. I like Edith Sitwell's British and American Poetry (1958) which gives the chronological view my sense of order requires and the bonus of her brilliant "Prefaces." Then, for great variety and out-of-the-way discoveries of old and new singing poetry, I like Walter de la Mare's Come Hither (1946), 


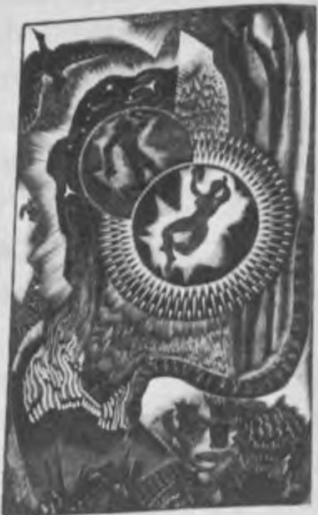

BIRDS, BEASTS AND FLOWERS Poems by D. H. LAWRENCE

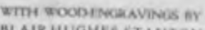
MLAIRHUGHES STANTON

THE CRESSET PRESS LTD LONDON MCMXXX

One of the volumes mentioned in Maureen Cobb Mabbott's essay, "My Last Bookshelf," D. H. Lawrence's Birds, Beasts and Flowers was first published in 1923. Shown above is the first illustrated edition (1930). Copy number 50 of 500 copies, from the collections of The University of Iowa Libraries. 
"an anthology for the youth of all ages." There is also the delightful, odd, stimulating Texts and Pretexts (1933) assembled and commented on by Aldous Huxley. After reading it one feels that the best way to present poetry is with prose but perhaps only with Huxley's prose.

And what of modern and postmodern poetry? As a junior at the University of Chicago in 1923, it is a wonder that a star from the blazing constellation of new poetry did not fall on my head some evening as I walked across the Midway. The Wasteland and Façade had passed over the year before but 1923's barrage added William Carlos Williams's Spring and All, e.e. cummings's Tulips and Chimneys, D. H. Lawrence's Birds, Beasts and Flowers, and Wallace Stevens's Harmonium. It seems inconceivable now that I did not notice this brilliant beginning of what has come to be known in poetry as the high modernist mode, except that I know who was standing in the light. Three of the university's greatest performers were occupying front stage-Professors Rickert, Lovett, and Linn, presenting Chaucer, Milton, and the nineteenth-century poets. Ask any fellow student. Had I time, or inclination, to look outside at the changing sky?

Thus, as far as I am educated in modern and postmodern poetry, I am self-educated, a process aided by the fact that after college I became a New Yorker and was present at all those limelight appearances of the poets at the 92nd Street $\mathrm{Y}$ in the thirties and after. And then, about the time the first edition of The Little Treasury of Modern Poetry (Oscar Williams) appeared in 1946, W. H. Auden came to the New School and in his "casual attire" gave a poetry course using The Little Treasury as a textbook. I lived to see the modern poets in Collected Works and to have favorites among them, Wallace Stevens particularly, but The Little Treasury, encrusted by memories of Auden's remarks, my awakenings and 35 years of companionship is for the shelf.

The period after the closing date of the Sitwell anthology in 1958 is included in a keepsake I have made, Music or a Message, Short Poems, 1932-1982. This represents the result of a personal wide-ranging search for "my own." Avoiding the passion of the period for irony and deprecation, the 117 poems fall loosely into three subject divisions, "The Desolation of Reality," "An Affirming Flame," and "The Living Connection." They share, besides an essential simplicity, the "haunted clarity" praised by James Dickey. A quartet of long-lived poets-Yeats, Frost, Williams, and Stevens-add weight to this private anthology, but the strongest section, to my pleased sur- 
prise, is "The Living Connection" and there the stars are Theodore Roethke, Robert Duncan, Denise Levertov, William Stafford, and the younger Charles Wright. The title of this section is from Lawrence's "The Uprooted."

People who complain of loneliness must have lost something,

lost some living connection with the cosmos, out of themselves,

lost their life-flow

like a plant whose roots are cut.

And they are crying like plants whose roots are cut.

But the presence of other people will not give them new rooted connection

it will only make them forget.

The thing to do is in solitude slowly and painfully put forth new roots

into the unknown, and take roots by oneself.

-D. H. Lawrence, Last Poems, 1932

After reading the poems that follow in this section, the reader is ready to join David Ignatow in the last one.

I have changed my mind about the world,

It should go on; it is beautiful.

"Above Everything," from Whisper to the Earth, 1982

As I complete the arrangement of my last bookshelf, I think that we never sufficiently celebrate the gift of memory. By its grace old age inherits a magic place containing, as it does, both youth and age, both new and remembered delight, as in the reading of books.

\section{A Bookish Postscript}

One look back and I have another armload of books. Without much ado I shall find a place for them on the shelf. Two are books of my favorite art forms: still life represented by Skira's Chardin and landscape painting presented in color plates and text in The Artist and the American Land, A Sense of Place, published by the Friends of the Earth. The third is Langdon Warner's The Enduring Art of Japan, an art particularly appealing to me because of its emphasis on all that is suggested rather than stated. Two other books I discovered for myself. They have seen me through periods of stress and illumination and may well be the last I cling to. They are John Cowper Powys's A Philosophy of Solitude (1933) which he refers to as A Handbook for Contemplation under Difficulties, 
and R. H. Blyth's Zen in English Literature (1942). I have seen this referred to only once when Karl Shapiro called it "A very strange and wonderful book." I would add "life giving." Lastly I include three small gems: Freya Stark's Perseus in the Wind (1948) "about things that are beyond our grasp yet visible to all," Italo Calvino's Invisible Cities (1974) about imagination and cities and dreams and Marco Polo and Kublai Khan, and Philip Kopper's A Christmas Testament (1982) beautiful and transfixing whether one takes it to be about a divine revelation, or a deathless myth.

M. C. M. 